\title{
"The Antipathy between French and Spaniards": Dress, Gender, and Identity in the Court Society of Early Modern Naples, 1501-1799
}

\begin{abstract}
The present article explores the inter-linkage between social and cultural values, related comportments, and dress in the courts of early modern Europe. More specifically, it examines the two competing cultural models of Spanish and French fashion, and the values and historical processes that determined their respective success in the contemporary courts of Europe in general and of Naples in particular. Owing to the importance of dress in the construction of gender roles, the article assesses the influence of dress among Neapolitan men and women separately. The findings show that men's fashions in Naples grosso modo followed European trends regarding both Spanish and French fashion from the sixteenth to the eighteenth century. Comparatively, female French fashions and their related forms of sociability would only be able to flourish from the reign of Charles of Bourbon onward.
\end{abstract}

\begin{abstract}
If we ask a Spaniard what he thinks of French clothes and their fancy, he will not only hold them to be ill-favored, but will be scandalized at something that causes such joy and lifts the heart; for to see a troop of French upon a festive day dressed in such variety of colors, with a thousand variations of feathers and cameos, embroideries, fringes, ornaments and gold laces, with so many hundreds of jewels, diamonds, pearls, rubies, emeralds and topazes that one would think the whole of India was landed on them [...] Yet the Spaniard will say that it is the greatest folly in the world [...] because in Spain the grave style is so much in use, and the colored habit so abhorred, that they force the hangman to wear a red or yellow livery to mark his shame and infamy. And if we hear the judgment of a Frenchman concerning the dress and style of a Spaniard, he will say that to go always in black is a sign of despair, the mark of a widow, or of a person gone bankrupt, even though black is one of the most honorable colors and argues modesty, reputation, authority and understanding. ${ }^{1}$
\end{abstract}

This Manichean categorization of the joyous, colorful, and extravagant French clothes, on one side, versus the grave, dark, and modest garments of the

$1 \mathrm{I}$ am indebted to the British Academy (grant number SG102076) for the generous funding of this article. Carlos García: La oposición y conjunción de los dos luminares de la tierra o Antipatía de Franceses y Españoles, ed. by Michel Bareau. Edmonton 1979, 200-202.

Ә Open Access. () 2019 Gabriel Guarino, published by De Gruyter. (cc) BY-NC-ND This work is licensed under a Creative Commons Attribution-NonCommercial-NoDerivatives 4.0 International License.

https://doi.org/10.1515/9783110635942-002 
Spaniards, on the other, fully conforms to the dichotomic thesis of its author, the physician Carlos García, aptly titled The opposition and conjunctions of the two planets of earth or the Antipathy between Frenchmen and Spaniards. First published in 1617, García's original agenda was to overcome the differences between the two nations in the wake of the recent double marriage of Philip III of Spain's daughter, Anna (1601-1666), to Louis XIII of France (1601-1643), and Philip of Spain (1605-1665) (the future Philip IV) to Isabel of France (1602-1644). Nevertheless, the book's various chapters emphasized precisely an "opposition" of character - roughly speaking, between extroverted Frenchmen and introverted Spaniards - which determined the way that Frenchmen and Spaniards, respectively, talked, ate, moved, and, of course, dressed. Accordingly, García postulated that the best definition of a Frenchman is "a reversed Spaniard, because the Spaniard ends where the French begins". ${ }^{2}$ Despite the apparent fancifulness of such a notion, the cultural animosity between the two was a common early modern trope, constantly fueled by the recurrent tide of military hostilities between France and Spain. ${ }^{3}$

The rivalry between these two styles will be a thread that runs throughout this article, as its aim is to trace the correlation between dress, power, and identity in early modern Naples, where Habsburgs and Bourbons reigned at different times. Specifically, the death of Charles II of Spain (1661-1700) in 1700 marked the end of the Habsburg dynastic rule of the Kingdom of Naples, which had begun in the sixteenth century. With the ascendancy to the throne of Charles II's successor, Philip V of Bourbon (1683-1746), the Neapolitan subjects of the Spanish Monarchy continued to be governed by a Spanish viceroy, albeit one that now represented the new dynasty. July 1707 marked yet another change of regime, as the Austrian Habsburgs took over the Kingdom of Naples from their Bourbon rivals as part of the War of the Spanish Succession, ushering in 27 years of Austrian viceregal rule. In 1734 Charles of Bourbon (1716-1788) reclaimed the Neapolitan Kingdom for Spain and was nominated by his father, Philip V, as King of the Two Sicilies, thus starting a new cadet branch of the Bourbon dynasty. During these shifts of power, dress interacted with various sources of identity, including an individual's dynastic allegiance, nation, gender, social status, religious confession, and so on. Indeed, according to Daniel Roche,

2 Ibid., 222.

3 See a recent collection of essays on this vast topic. Anne Dubet and José Javier Ruiz Ibáñez (eds.): Las monarquías española y francesa (siglos XVI-XVIII). Dos modelos políticos? Madrid 2010. 
connected with religious convictions, faith and powerful symbolic expressions, clothing is a prop to beliefs and observances, as it is to social representations. At every moment clothing expresses links with authority, suggests the sexual hierarchy of roles in the family, points to the power of beliefs both in its details and in its totality. ${ }^{4}$

Accordingly, looking separately at men's and women's fashions, this article will identify the national origins of these clothes, the values they inspired, their means of diffusion in Naples, and their change through time.

\section{Between Habsburgs and Bourbons: Men's Fashions in Spain and Naples}

Some of the cultural differences between Spanish and French men's outfits in the early modern period have been attributed to the divergent visions of ideal image-making cultivated by the two leading European courts of the time. Political and cultural historians have juxtaposed a Habsburg Spanish tradition of "private kingship", also known as "hidden monarchy", initiated by Charles V (1500-1558) and continuing throughout the rule of his Habsburg heirs, with one of "public kingship" offered by the French Bourbons, best exemplified by Louis XIV's (1638-1715) Versailles. According to this argument, Spanish kings chose to remain remote and inaccessible to most of their courtiers, rarely appearing in public and even then only behind a curtain. Those hidden monarchs who best played this role, like Philip II (1527-1598) and Philip IV, acquired an aura of mystery and awe. ${ }^{5}$ The Habsburgs' physical withdrawal and personal modesty was also reflected in their preferred garments, faithfully depicted in their official portraits. From Charles V to Charles II, these included the same unassuming black clothes described by García. ${ }^{6}$ Moreover, the portraits usually rejected the visible signs of royalty - a scepter, a crown, a canopy - that typically identified and exalted royal persons. Elliott explains this choice of the

4 Daniel Roche: A History of Everyday Things. The Birth of Consumption in France, 1600-1800, transl. by Brian Pearce. Cambridge 2000, 195.

5 See for example: John H. Elliott: The Court of the Spanish Habsburgs. A Peculiar Institution?, in: id.: Spain and its World. Collected Essays. New Haven, CT 1989, 142-161; and Carmelo Lisón Tolosana: La imagen del rey. Monarquía, realeza y poder ritual en la Casa de los Austrias. Madrid 1991.

6 Fernando Checa Cremades: Monarchic Liturgies and the "Hidden King”. The Function and Meaning of Spanish Royal Portraiture in the Sixteenth and Seventeenth Centuries, in: Allan Ellenius (ed.): Iconography, Propaganda, and Legitimation. Oxford 1998, 89-104. 
Habsburg monarchs as the epitome of political sophistication, whereby a purposefully understated execution of royal portraiture reflected the unquestioned assurance of Spain's claim to European supremacy. ${ }^{7}$ The French ideal, on the other hand, best explained in Burke's masterful analysis of Louis XIV's management of his image, espoused an ever-present, attention-seeking monarch, whose court revolved around his daily movements. Accordingly, Louis' iconography abounds precisely in the hyperbole, allegorical imagery, and typical accessories of monarchical power that the Habsburgs chose to omit. His portraits depicted him in the flamboyant and colorful clothes that would become the standard of European fashion from the last decades of the seventeenth century through the end of the eighteenth. ${ }^{8}$

From the middle of the sixteenth century to the middle of the seventeenth, in concordance with wider European trends, Neapolitan aristocrats appear to have assiduously followed the example presented at court by the resident Spanish viceroys. The viceroys, in turn, belonging invariably to the titled nobility of Spain, followed men's court fashions of Madrid. ${ }^{9}$ The Neapolitan nobility's adherence to the fashion of Spain conformed to its general loyalty to the Habsburgs; but it also ought to have come quite naturally, as male black outfits were already fashionable during the fifteenth-century Aragonese rule of the Kingdom of Naples. ${ }^{10}$ This also made sense in terms of the nobility's corporate calculations, as fealty to the Spanish crown granted the titled nobility access to military posts, state offices, and pensions, as well as honorific privileges like admission to chivalric orders, titles, and various ceremonial honors displayed at court. ${ }^{11}$ Contemporary assessments of the Spanish influence on Neapolitan dress are also confirmed by the archival findings of Scognamiglio Cestaro and Musella Guida, whose examinations of sixteenth-century Neapolitan inventories corroborate the predominant use of black clothes among the Neapolitan nobility. ${ }^{12}$

7 John H. Elliott: Power and Propaganda in the Spain of Philip IV, in: id., Spain and its World, 162-188, here 167.

8 Peter Burke: The Fabrication of Louis XIV. New Haven, CT 1992.

9 For fashions in Naples during this period see Adelaide Cirillo Mastrocinque: Cinquecento napoletano, in: Ernesto Pontieri (ed.): Storia di Napoli, vol. 4. Naples 1976, 515-575.

10 Lina Montalto: La corte di Alfonso I di Aragona: vesti e gale. Naples 1922, 86, 88.

11 Angelantonio Spagnoletti: Principi italiani e Spagna nell'età barocca. Milan 1996, esp. 51-128. For recent studies dealing with the Neapolitan court see John A. Marino: Becoming Neapolitan. Citizen Culture in Baroque Naples. Baltimore, MD 2010; and Gabriel Guarino: Representing the King's Splendour. Communication and Reception of Symbolic Forms of Power in Viceregal Naples. Manchester 2010.

12 Silvana Musella Guida and Sonia Scognamiglio Cestaro: Le origini della moda napoletana, in: Proceedings of the XIII International Congress TICCIH: Industrial heritage and urban 
A more detailed look at the constitutive elements of the Spanish dress of the period shows that it reflected the severe and morally strict values of the Catholic Reformation shared by both Spaniards and Neapolitans. Spanish men's fashions abandoned the soft and sexually effeminate elements typical of the Italian Renaissance, like skirts and long haircuts. They included, instead, mid-thigh-length breeches and a long-sleeve blouse topped by a padded doublet. Men sported full beards and short-trimmed haircuts. The predominant color of these garments was black, with the exception of the white ruff and white cuffs that completed the outfit. According to John Harvey, the values associated with the color black - "self-effacement and uniformity, impersonality and authority, discipline and self-discipline, a willingness to be strict and a willingness to die"13 - were conducive to the maintenance of an imperial order. For this reason black was the color of choice not only for Spain but also for various other nations at the peak of their power, including fifteenth-century Burgundy, early modern Venice and Holland, and England in the nineteenth century. Nevertheless, this did not come at the expense of a sumptuous appearance at court. The expensive process of achieving black dye, significantly improved during this time with the novel use of logwood, became a status marker per se, especially when used on such expensive textiles as silk and velvet. ${ }^{14}$ Accordingly, when Baldassare Castiglione advised in his handbook for the ideal courtier (first published in 1528) that the most befitting clothes at court were the black and austere garments of Spain, he was preaching to the choir. ${ }^{15}$ By 1590, as depicted in the contemporary fashion plates of Cesare Vecellio, the nobles of Naples and Milan were wearing the dress of their Spanish rulers; but so were the politically independent Genoese, Romans and Florentines. ${ }^{16}$

After the middle of the seventeenth century, the plot thickens. The portraits both of Spanish viceroys of Naples and of the contemporary Neapolitan nobility,

landscape, Terni-Rome, 14-18 September 2006, 1-28. URL: http://works.bepress.com/theinterna tionalcommitteefortheconservationoftheindustrialheritage/12/ (11 Sep. 2018).

13 John Harvey: Men in Black. London 1995, 156.

14 For the influence of black in Spanish and Italian male dress see: Amedeo Quondam: Tutti i colori del nero. Moda "alla spagnola" e "migliore forma italiana”, in: Annalisa Zanni and Andrea di Lorenzo (eds.): Giovanni Battista Moroni. Il cavaliere in nero. Immagine del gentiluomo nel Cinquecento. Milan 2005, 25-45; and José Luis Colomer: Black and the Royal Image, in: id. and Amalia Descalzo (eds.): Spanish Fashion in Early Modern Europe. The Prevalence and Prestige of Spanish Attire in the Courts of the 16th and 17th Centuries, vol. 1. London 2014, $77-112$.

15 Baldassare Castiglione: Il libro del Cortegiano, ed. by Luigi Preti. Turin 1965, book II, ch.27. 16 Indeed, the author asserted that this was the fashion of "most Italian gentlemen". Cesare Vecellio: Habiti antichi et moderni di tutto il mondo. Paris 1859, 22. 
along with literary descriptions in contemporary local memoirs, show that men's dress underwent some change. ${ }^{17}$ Apart from the introduction of longer coiffures and the restriction of facial hair to long and curved moustaches, the main alteration was the elimination of the expensive ruff in favor of the golilla. This was a rigid cardboard support over which came a simple white collar, the Walloon, which was introduced by Philip IV in 1623 in his Capitulos de Reformación with the intention of reducing superfluous luxuries during times of economic strain. Together with the black attire the golilla became a prerequisite for anyone who wished to be accepted at the court of Madrid. Although kings were exempted from sumptuary prescriptions, Philip IV made sure to regularly wear the rigid collar as a personal example of self-imposed austerity. Consequently, the golilla would turn into the quintessential symbol of the somber traditional Spanish attire, at a time when it was being challenged by French fashion. ${ }^{18}$ It is precisely this paragraph from Spanish attire to French fashion that would be at the center of a vivid, long-lasting public debate in both Spain and Naples, which would prove to have significant economic, social and cultural consequences.

Crystallizing in Louis XIV's Versailles in the last two decades of the seventeenth century and continuing throughout the eighteenth, the standard ensemble of a European gentleman dressed in the French way consisted mainly of a matching three-piece suit made up of a knee-length cassock known as justeaucorps, an under jacket, and breeches. Distinctive accessories included a silken cravat (the precursor of the modern tie), and a periwig, which changed in size and shape throughout the eighteenth-century. This was a sumptuous version of the contemporary French military habit, the adoption of which by Louis XIV, as the new court dress, marked his chauvinistic attitude and insatiable appetite for personal and dynastic glory. ${ }^{19}$ Despite their military origin, however, the French garments were also permeated with feminine attributes. The adoption of these attributes went hand in hand with the central role acquired by women at Versailles in new, refined forms of sociability and entertainment which later diffused to the entire continent, bringing about the feminization of the European male courtiers enmeshed in these forms of sociability. The integration of

17 For the viceregal portraits in Spanish Italy see Valeria Manfrè and Ida Mauro: Rievocazione dell'immaginario asburgico. Le serie dei ritratti di viceré e governatori nelle capitali dell'Italia spagnola, in: Ricerche sul Seicento Napoletano. Saggi e Documenti. Napoli 2011, 107-135.

18 Ruth Matilda Anderson: The Golilla. A Spanish Collar of the Seventeenth Century, in: Waffen und Kostümkunde 11 (1969), 1-19.

19 For Louis XIV's dress and its success in Europe see Philip Mansel: Dressed to Rule. Royal and Court Costume from Louis XIV to Elizabeth II. New Haven, CT 2005, 1-15. 
feminine attitudes into daily life was expressed in men's increasing concern with their appearance, spending long grooming sessions in front of the dressing table, applying cosmetics, and wearing feminine accessories. ${ }^{20}$

The introduction of French men's fashion in the Spanish court began with Charles II. Although this has been attributed to the influence of his French wife, Marie Louise of Orléans (1662-1689), following their wedding in 1679, already a decade earlier the young monarch was reported wearing French dress. French outfits, however, were limited to informal occasions, as the court etiquette in Madrid required the king and his court to maintain the traditional Spanish attire. In fact, the chronically infirm king, often described as a "martyr" to the strictness of Spanish ceremonial, was described during the last years of his troubled existence as unable to give audience because his ill health would not allow him to wear the cumbersome golilla. ${ }^{21}$ With the accession to the Spanish throne of Philip V of Bourbon following the death of the childless Charles, in 1700, it would be logical to expect the advance of French fashions with a greater impetus than ever before. Yet, during the first years of his reign in Spain, Philip V was reported to stick to the existing court dress. This was suggested to him by none other than his grandfather Louis XIV, with an eye to achieving much-needed legitimation of the new dynasty by stressing continuity with the previous regime. This was sound advice in the light of the strong challenge mounted by the Austrian Habsburgs throughout the War of the Spanish Succession, which included the self-declaration of Archduke Charles (1685-1740) as King of the Spanish monarchy and his installation in Barcelona in 1705. Accordingly, Philip V and his court would abandon the golilla only after the Bourbon monarch felt safe enough in his position, following the crushing defeat inflicted on his Habsburg foe at the Battle of Almansa in 1707. From then on, and throughout the eighteenth century, French fashions would become the rule in the Spanish court. Nevertheless, the fact that its full acceptance there would take more than three decades after its adoption by most European court circles shows the strong aversion of Spaniards towards it. ${ }^{22}$

20 For the more ridiculed aspects of Italian male sociability see Roberto Bizzocchi: Cicisbei. Morale privata e identità nazionale in Italia. Rome 2008.

21 For men's fashions in Charles II's reign see Amalia Descalzo Lorenzo: Spanish Male Costume in the Habsburg Period, in: ead. and Colomer, Spanish Fashion, vol. 1, 28-31.

22 For eighteenth-century Spanish court dress see ead.: El traje francés en la corte de Felipe V, in: Anales del Museo Nacional de Antropología 4 (1997), 189-210; Arianna Giorgi: De vestidos y gala. Influencias francesas en el apariencia y el aparato de la corte de la primera mitad del siglo XVIII, in: María José Pérez Álvarez et al. (eds.): Campo y campesinos en la España Moderna. Culturas políticas en el mundo hispano. León 2012, 2035-2045. 
Moreover, the newly adopted garments would become the object of censure for moralists and satirists throughout the eighteenth century, who objected to the sizable expenses incurred for the showy garments and accessories, and deplored their effeminacy. A contemporary critic ridiculed the spending of Spaniards à la mode in "powders, trimmings, beauty-marks and bracelets, and all the dissimulated cosmetics proper for a lady. They are men when naked, women when they are dressed." ${ }^{23}$ In other words, notwithstanding the adoption of French garments in the eighteenth century, Spanish traditionalists considered them to be an attack on masculine respectability and traditional national values.

The Neapolitan case seems to present a much readier process of assimilation. The introduction of French dress among the Neapolitan nobility coincided with its acceptance in the rest of the Italian peninsula, around the middle of the seventeenth century. ${ }^{24}$ As early as 1648 , a local chronicler described French barbers in Naples buying the hair of condemned criminals from the hangman, out of which "they wove false heads of hair, which they call wigs." 25 This point is also corroborated by contemporary portraiture. Dombrowski, studying the sculptures of the Neapolitan aristocracy of the sword during the last years of the Thirty Years' War, outlines the clearly French characteristics of their dress. The best example is provided by the statue of Carlo Maria Caracciolo - completed in 1643, two years after his death - clearly documenting "his French hairdo, his French cravate, the justeaucorps, a kind of short soutane, the lace ribbon peering out from under his armour."26 Predating the aforementioned censorious judgments of the Spanish, Neapolitan traditionalist commentators condemned the senseless extravagance and effeminacy of the French clothes. For example, Carlo Celano, writing during the last two decades of the seventeenth century, ridiculed with gusto the fashionable young nobles wearing a bounty of jolly colors, great quantities of ribbons on the arms and the neck,

23 Quoted in Álvaro Molina Martin and Jesusa Vega González: Vistiendo al nuevo cortesano. El impacto de la "feminización", in: Nicolás Morales and Fernando Quiles (eds.): Sevilla y corte. Las artes y el Lustro Real (1729-1733). Madrid 2010, 165-178, here 173.

24 Adelaide Cirillo Mastrocinque: Usi e costumi popolari a Napoli nel Seicento. Rome 1978, 116-118.

25 Innocenzo Fuidoro: Successi del governo del conte d'Oñatte MDCXLVIII-MDCLIII, ed. by Alfredo Parente. Naples 1932, 72.

26 Damian Dombrowski: "Il Genio Bellicoso di Napoli”. The Warrior Ethic of the Neapolitan Nobility and its Threats in the Mirror of Portraiture, in: Klaus Bussmann and Heinz Schilling (eds.): 1648. War and Peace in Europe. Ex Cat. Münster / Osnabrück, vol. 2: Art and Culture. Munich 1998, 525-531. URL: https://www.lwl.org/westfaelischer-friede-download/wfe-t/wfe-txt257.htm (11 Sep. 2018). 
and applying very close shaves because, in Celano's words, “aiming to look like women, they must not be hairy." 27

This swift adoption of French fashion by the old Neapolitan nobility can be explained by various factors. The economic and political dynamics of seventeenthcentury Naples favored the ascension of parvenus from mercantile extraction and the further reinforcement of the nobility of the robe at the expense of the nobility of the sword - a process that had been promoted by a monarchical project of "divide and rule”. Thus, the old nobility's symbolic reaction to a substantial loss of its political and economic power was to keep up appearances by indulging more than ever before in luxurious expenses of conspicuous consumption, like the extravagant and expensive French attire. ${ }^{28}$ The Neapolitan nobility's adherence to French dress seems to have also been encouraged by the Spanish viceroys, who started to wear it around the same time as the more fashionably inclined Spaniards in Madrid were starting to do the same. For example, according to the chronicler Antonio Bulifon, in the summer of 1672 the viceroy the Marquis of Astorga (1672- 1675) introduced the French military dress, "showing his pleasure that the gentlemen wore the same". ${ }^{29}$ Astorga's successor, the Marquis of Los Vélez (1675-1683), started wearing a wig in April 1679. Well aware of the effect that viceroys' dress had on the local nobility, the chronicler predicted that this "will be seen as an example to confirm those who wore it before him, and it will also create a desire to wear it for those who did not wish to do so."30 According to the philosopher Paolo Mattia Doria, the need to promote French civilization might have had a more concrete political goal. Writing with hindsight, Doria claimed that in the wake of a probable Bourbon succession to the Spanish throne, the viceroy the Count of Santisteban (1687-1696) redoubled the efforts of previous viceroys to promote French fashions in Naples in order to "extirpate from the hearts of the kingdom's peoples that old hatred towards the French nation, which has been planted meticulously by the very same Spaniards." 31

Indeed, the Bourbon dynastic passage in 1700 did not pass seamlessly. As in the other territories involved in the War of Spanish Succession, Neapolitans were

27 Carlo Celano: Degli avanzi delle poste, vol. 1. Naples 1676, 11.

28 For this explanation see Alida Clemente: Note sulla legislazione suntuaria napoletana in età moderna, in: Dimensioni e problemi della ricerca storica 1 (2011), 133-162, here 143.

29 Antonio Bulifon: Giornali di Napoli dal MDXLVII al MDCCVI, ed. by Nino Cortese. Naples 1932, 192.

30 Innocenzo Fuidoro: Giornali di Napoli dal MDCLX al MDCLXXX, vol. 4, ed. by Vittoria Omodeo. Naples 1943, 257.

31 Paolo Mattia Doria: Massime del governo spagnolo a Napoli, ed. by Vittorio Conti. Naples 1973, 47. 
split in their support between those siding with the Bourbons, locally known as the Gallispani, and their rivals, the Filoasburgici. The 1701 Conspiracy of Macchia, orchestrated by the Habsburg faction, despite its ultimate failure testifies to the weak grip of the new Bourbon dynasty on Naples. Philip V's visit to Naples on February 1702 as a result of pro-Habsburg sentiments can be interpreted as a desperate attempt to consolidate his tenuous rule there. ${ }^{32}$ Significantly though, Philip's public appearance in Naples was unapologetically French, unlike his decision to wear the traditional Spanish dress during these same years while in the Madrid court. According to Bulifon, Philip wore "a justeaucorps in the color of fire, ornate by golden frills, and his hat, in addition to a white feather, was trimmed with a precious stone." ${ }^{33}$ There is no mention of the type of collar he wore, but given the rest of his outfit it is safe to assume he was wearing a cravat rather than a golilla. This hypothesis is reinforced by the curious request made to the Spanish king, during the time of his visit, by the Neapolitan association of solicitors. They requested his permission to wear French clothes, and most importantly, to relinquish the golilla when presenting a case at the courts of justice. Although there was no particular law obliging them to appear in one way or another, the solicitors expressed their apprehension of being ill-regarded by the judges if they abandoned the conventional Spanish dress. The king granted the motion, although informally, given that no formal precedents were applicable. ${ }^{34}$

This unusual request testifies to the limits of the appeal of French fashions in Naples. The traditionalist judges who insisted on maintaining the Spanish decorum in dress effectively comprised a powerful group of legal professionals, belonging to the local nobility of the robe, who were empowered by the state to put a check on the political might and corporate privileges of the old feudal nobility of the sword. These became a veritable thorn in the side of their aristocratic rivals after the middle of the seventeenth century, and by the time of Charles' visit the majority of state councils were manned by them. ${ }^{35}$ Thus, the corporate rivalry

32 For a recent study of the conspiracy see Francesca Fausta Gallo: La congiura di Macchia. Cultura e conflitto politico a Napoli del primo Settecento. Rome 2018.

33 Antonio Bulifon: Giornale del Viaggio d'Italia Dell'Invittissimo e gloriosissimo Monarca Filippo V Re delle Spagne, e di Napoli, etc. Nel quale si dà ragguaglio delle cose dalla M.S. in Italia adoperate dal dì di 6 d'Aprile, nel quale approdò in Napoli, infin'al dì 16 di Novembre 1702 in cui s'imbarcò in Genova, per far ritorno in Ispagna. Naples 1703, 14.

34 See Giuseppe Galasso: Napoli spagnola dopo Masaniello. Politica, cultura, società, vol. 2. Florence 1982, 647.

35 For some of these developments see Anna Maria Rao: Napoli nel Settecento. Naples 1983, 26-32; Raffaele Ajello: Il problema storico del Mezzogiomo. L'anomalia socioistituzionale napoletana dal Cinquecento al Settecento. Naples 1994, 236-238; Cinzia Cremonini: Riequilibrare il 
between the two aristocratic models was also expressed in their looks. The iconographic evidence clearly shows that the robed nobility, locally known as the ceto togato, kept wearing a black toga and a golilla after the middle of the eighteenthcentury Figure 1. This was in plain contrast to the ever-more extravagant French clothes of the feudal nobles Figure 2, who had been pressured to maintain a particularly grand style following the establishment of the independent monarchical court of Charles of Bourbon in $1734 .^{36}$

This split between a group of "progressives" favoring French clothes and a group of "traditionalists" wearing the old garments became even more pronounced in Spain after the middle of the eighteenth-century, when the afrencesados became a stereotyped image of spendthrift, indulgent, and effeminate men who had abandoned what were regarded as long-standing national values. ${ }^{37}$ It is in this context that we should interpret a contemporary anonymous Spanish assessment of Charles of Bourbon, King of Naples: "He dearly loves and favors the Spanish nation (which one may call his) and it is known in him an affectionate disposition to benefit her. He thinks like a Spaniard and makes decisions as a Christian. He dresses unwillingly in the French way and he carries the golilla in his conscience." 38 This fanciful assertion tells us more about the traditionalist values of the speaker than about the object of his remarks. In reality, it can be entirely refuted by the fabulous expenditures supporting Charles' wardrobe, much of which consisted of the expensive ceremonial versions of French outfits that he frequently wore at court. What is more, the various luxuries consumed by Charles and his Neapolitan court were produced by French artisans and imported by French and Swiss merchants, in a way that directly harmed local producers. ${ }^{39}$

sistema: mutazioni e permanenze in Italia tra 1706 e 1720. Alcune considerazioni, in: Cuadernos de Historia Moderna 12 (2013), 177-188.

36 Sonia Scognamiglio Cestaro: Leggi "scomode", clientele e fedeltà. Aspetti socioistituzionali ed economici della legislazione suntuaria del Regno di Napoli in Età moderna, in: L'économie du luxe en France et en Italie, Journées d'étude organisées par le Comité francoitalien d'histoire économique (AFHE-SISE), Lille, Ifresi 4-5 mai 2007. URL: http://lodel.ehess.fr/ afhe/document.php?id=454 (11 Sep. 2018).

37 Martin and Vega González, Vistiendo al nuevo cortesano, 172-175.

38 Anon.: Registro curioso de lo interior y exterior de la Corte de Napoles, Biblioteca Nacional de España, MS. 11036, fol. 37v.

39 For these processes in Bourbon Naples see: Silvana Musella Guida and Sonia Scognamiglio Cestaro: Il 'tempo eroico' e la politica commerciale di Montealegre. La Manufacture Royale de Joseph Fleuriot et François Boucharlat, in: Napoli Nobilissima. Rivista di arte, filologia e storia 10 (2009), 195-206; Sonia Scognamiglio Cestaro: Le istituzioni della moda. Dalle strutture corporative all'economia politica. Napoli e Francia (1500-1800). Bologna 2015, 391-418; and Alida Clemente: Il lusso “cattivo”. Dinamiche del consumo nella Napoli del Settecento. Rome 2011. 


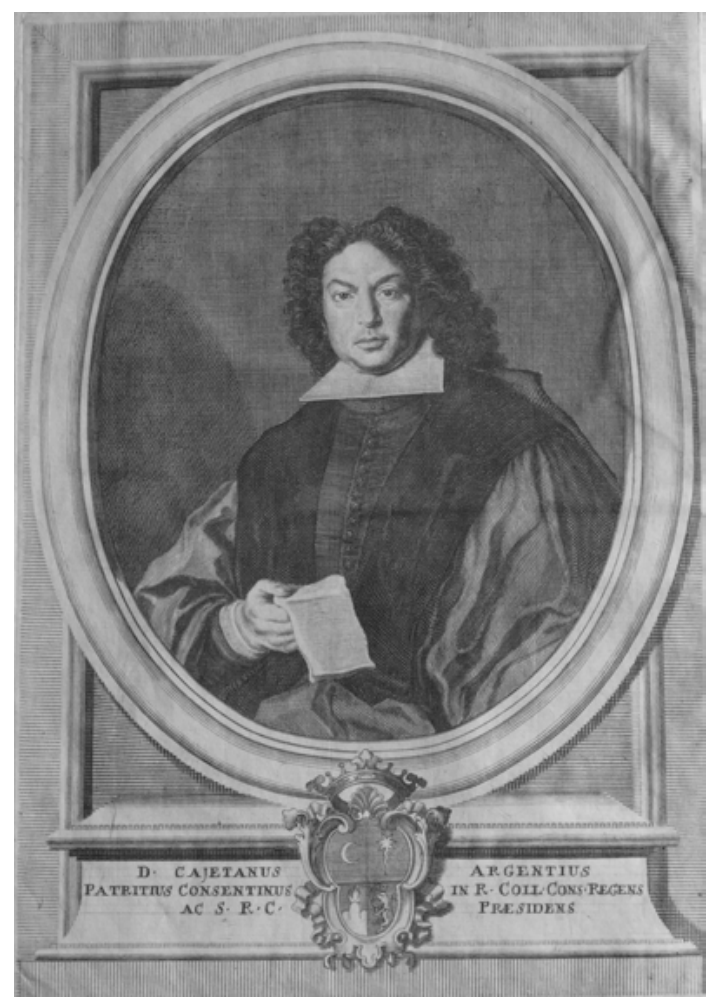

Figure 1: Portrait of Gaetano Argento, in: Funerali nella morte del signor duca d. Gaetano Argento: reggente della Real cancelleria, presidente del S.R.C. e gran veceprotonotario del regno di Napoli: celebrati nella Real chiesa di S. Giovanni a Carbonara, con varj componimenti in sua lode di diversi autori. Naples 1731, frontispiece.

\section{Challenging the Boundaries of Respectability: Women's Fashions in Spain and Naples}

Recent scholarship on gender in the Iberian world from the mid-sixteenth to midseventeenth century has shown the connection between female education, women's expected gender roles and daily experiences, and their attitudes to their own bodies as reflected by their sartorial choices. ${ }^{40}$ Spanish pedagogical texts dealing

40 A good starting point is the collection of essays: Alain Saint Saëns (ed.): Religion, Body and Gender in Early Modern Spain. San Francisco, CA 1991. 


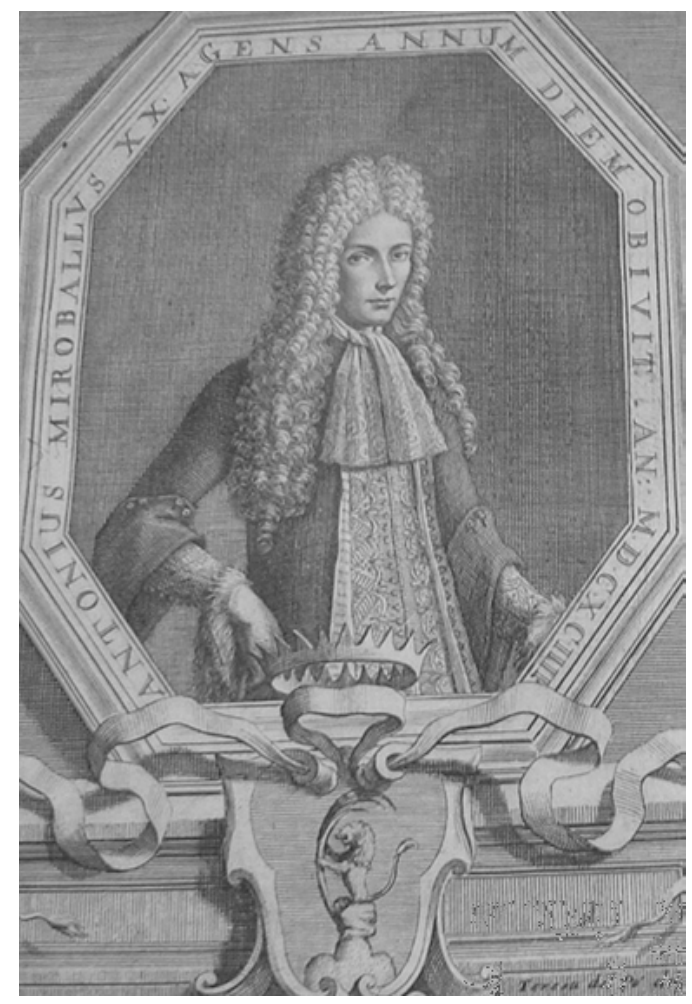

Figure 2: Portrait of Don Antonio Miroballo, in: Antonio Bulifon: Funerali nella morte del Signor D. Antonio Miroballo celebrati nella Real Chiesa di S. Gio: a Carbonara. Naples 1695.

with female education written during the militant years of the Catholic Reformation reverberate with the anxieties of the age. For example, the influential Education of a Christian Woman (1523), by Juan Luis Vives, advised that the main purpose of female learning should be the maintenance of chastity. Specifically, in regards to appearance, Vives condemned deep cleavages, eccentric coiffures, make-up and perfumes, perceiving these as external signs of dishonorable intentions, which invited men to act upon the lascivious thoughts that they triggered. ${ }^{41}$ Similarly, Fray Luis de León, in his Manual for the Perfect Wife (1583), explained

41 Juan Luis Vives: Formación de la mujer cristiana, in: id.: Obras Completas, ed. by Lorenzo Riber, vol.1. Madrid 1947, 985-1175. On proper clothes for young ladies, married women, and widows, see respectively: ibid., 1015-1026, 1116-1120, 1169-1171. 
clearly that just as it was natural for men to speak and to be at the center of attention, so it was becoming for women to be enclosed and covered. He stressed the point by endorsing the example of the Chinese, who "twist the feet of girls when they are born, so when they grow up to become women they are not able to go outside." ${ }^{42}$ Significantly, these ideas prevailed among the European Catholic clergy during the militant phase of the Tridentine Reformation, when intensified attacks came from diverse sources, including schools for catechisms, sermons, and pamphlets. Along with these rhetorical tools, extensive use was made of Baroque imagery in churches, which stressed the simplicity of dress of Madonnas and female saints in order to instruct women on their expected social roles. ${ }^{43}$

Women's court dress closely reflected these values. The effacement of the feminine body in Spanish attire from the 1550s to the 1630s, at least - not coincidentally the militant years of the Catholic Reformation - matched the deep suspicion of religious authorities towards female sexual temptations. The garments themselves included a linen corset tightly fitted to the waist, upon which came a confining bodice that flattened the bust. To this was added the farthingale (known in Spanish as verdugado), a bulky underskirt constructed of hoops of wood or whalebone that extended from the waist down to the feet and gave its wearer the shape of a bell. Its sizeable volume prevented a comfortable proximity to the table, and noble women had to be fed by their servants. Finally, the most popular head cover, used by Spanish women of all ranks, was a long black thick veil to be worn outdoors, known as mantilla, that almost entirely covered the face and hair. Practically, owing to these garments, Spanish women were covered from head to toe, with the aim of promoting sexual chastity and preserving family honor. ${ }^{44}$

However, a deeper look at these sartorial choices shows that women were able to fight back in subtle ways within the system. Those same garments that were promoted by Catholic-Reformation moralists proved to be exploitable for feminine subterfuge. Various recent studies have emphasized the ambivalence of the

42 Fray Luis de León: La Perfecta Casada. Madrid 1583, 71.

43 On Catholic Reformation imagery see Sarah F. Matthews Grieco: Pedagogical Prints. Moralizing Broadsheets and Wayward Women in Counter Reformation Italy, in: Geraldine A. Johnson and ead. (eds.): Picturing Women in Renaissance and Baroque Italy. Cambridge 1997, 61-87.

44 On these Spanish-inspired constrictive clothes in Italy see Grazietta Butazzi: Vesti di "molta fattura". Reflections on Spanish-Influenced Fashion in the Second Half of the Sixteenth Century, in: Annalisa Zanni (ed.): Velluti e moda: tra XV e XVI secolo. Milan 1999, 169-175; and Gabriel Guarino: Regulation of Appearances During the Catholic Reformation. Dress and Morality in Spain and Italy, in: Myriam Yardeni and Ilana Zinguer (eds.): Les deux réformes chrétiennes. Propagation et diffusion. Leiden 2004, 492-510. 
tightly-dressed and veiled attire of Spanish women, known as tapadas, which was widely introduced during the reign of Philip II. After at first encouraging tapado attire, moralists started to condemn it, fearing that women were abusing the anonymity it offered in order to escape the control of their male relatives. Not surprisingly, then, the bans promulgated against the use of veils, beginning with Philip II in 1590 and reissued throughout the reigns of his Habsburg successors, failed, as they encountered strong female resistance. ${ }^{45}$ The same was true for the farthingale when, towards the 1630s, it was reintroduced to Spain in its exaggerated French version known as the guardainfante. According to Amanda Wunder, this change in style inspired an outpouring of vitriolic criticism that stemmed in part from the garment's association with French fashion. The implication of its new appellation, guardainfante (loosely translatable as baby-keeper), was that women not only used it to conceal their legs but also abused it to hide illegitimate pregnancies. Moreover, various contemporary reports told of women utilizing guardainfantes to conceal contraband goods or to hide their lovers. ${ }^{46}$ It seems, then, that the selfeffacing qualities of Spanish fashion proved to be carriers of freedom, just as they could be symbols of oppression, and the sumptuary laws promulgated against veils and guardainfantes were generally ignored. This points toward a certain degree of agency that women were able to claim for themselves despite the constant attempts of oppressive vigilance and control imposed on them.

How well did these fashions do in Naples? Both iconographic and written evidence, from contemporary chroniclers, memorialists, and travel writers, shows the proliferation of Spanish fashion throughout this period. For example, in tune with post-Tridentine moralistic values, according to Cesare Vecellio, the "grave and pompous" women of Naples took great care in appearing "closed and secured in their bosoms". He also mentions their predilection for the bellshaped farthingale, as well as the same sort of face cover - a thin black mantilla favored by Spanish women, which they wore when strolling outside the confines of their homes. ${ }^{47}$ Curiously, the sumptuary law issued by the viceroy the Duke of Alcalà (1559-1571) in 1559 reinforced the widespread use of the farthingale in Naples by sanctioning the use of the bulky skirts, although requiring that they be

45 See, for example: Laura R. Bass and Amanda Wunder: The Veiled Ladies of the Early Modern Spanish World. Seduction and Scandal in Seville, Madrid and Lima, in: Hispanic Review 77 (2009), 97-144. For a wide temporary and geographic scope of the veil see Maria Giuseppina Muzzarelli: A capo coperto. Storie di donne e di veli. Bologna 2016.

46 Amanda Wunder: Women's Fashions and Politics in Seventeenth-Century Spain. The Rise and Fall of the Guardainfante, in: Renaissance Quarterly 68 (2015), 133-186.

47 Vecellio, Habiti antichi, 224. 
kept within prescribed limits. ${ }^{48}$ Based on evidence from the diarist Antonio Bulifon, it seems that Neapolitan women maintained this fashion until well after the middle of the seventeenth century. Describing their garments in an entry from 1670, Bulifon reports them as wearing "a thin, black, silk mantle, called veil", which allows them to "go all covered". 49

The enduring success of the grave and modest garments can be explained by the close affinity between Neapolitans and Spaniards regarding sexual mores, as stated above, and the resulting emphasis on maintaining the integrity of family honor. Indeed, this like-mindedness can be understood within the larger frame of a "Mediterranean code of honor and shame" identified by social anthropologists and cultural historians. In full concordance with the aforementioned prescriptions of Spanish moralists, there is a wide agreement that female honor in Mediterranean societies relied on the purity of women's sexual behavior, namely on sexual abstinence before marriage and fidelity to their husbands thereafter. The men of the family whose honor was tarnished through female sexual impropriety - either via the loss of virginity for unmarried daughters or by means of adultery in the case of wives - could avenge it with blood. ${ }^{50}$ Spanish testimonies of honor killings abound during the early modern era. For example, two contemporary Spanish soldiers, Alonso de Contreras and Don Diego, Duke of Estrada, killed their wives and their lovers, in similar circumstances, when they caught them committing adultery. ${ }^{51}$ Both men displayed sorrow when remembering their murderous actions, while implying that such

48 Lorenzo Giustiniani (ed.): Nuova collezione delle prammatiche del Regno di Napoli, vol. 7. Naples 1804, 26.

49 Bulifon, Giornali, 188.

50 Specifically, for the case of Spain, see: Julio Caro Baroja: Honor and Shame. A Historical Account of Several Conflicts, in: John George Peristiany (ed.): Honour and Shame. The Values of Mediterranean Society. London 1965, 79-139, and Bartolomé Bennassar: The Spanish Character. Attitudes and Mentalities from the Sixteenth to the Eighteenth Century, transl. by Benjamin Keen. Berkeley 1979, 213-236. For Spanish Naples see Gabriel Guarino: The Reception of Spain and its Values in Habsburg Naples. A Reassessment, in: Melissa Calaresu, Joan-Pau Rubiés and Filippo de Vivo (eds.): Exploring Cultural History. Essays in Honour of Peter Burke. Aldershot 2010, 93-110. For a comparative approach see the various contributions in: Acta Histriae 9 (2000), special issue on Honour. Identity and ambiguity of an informal code (The Mediterranean, 12th-20th centuries).

51 See, respectively: Alonso de Contreras: Discurso de mi vida. Desde que salí a servir al Rey a la edad de catorce años, en el año de 1595, hasta fin del año 1630, el 1 de octubre, en que comencé esta relación, in: José Cossio (ed.): Autobiografías de soldados (siglo XVII), Madrid 1956, 76-143, here 107; and Don Diego Duque de Estrada, Comentarios del desengañado de si mesmo, prueba de todos estados y elección del mejor de ellos, o sea Vida del mesmo autor, que lo es Don Diego Duque de Estrada, in: ibid., 251-484, here 268. 
actions were compulsory for men wishing to salvage their honor. Indeed, a Spanish law under Habsburg rule sanctioned these forms of popular justice, proclaiming that "if a married woman commits adultery, she and her fellow adulterer shall be submitted to the power of the husband, and he may do whatever he wishes with them and their property, though he cannot kill one and spare the other." 52

The proliferation of similar practices among Southern Italian elites is evidenced by a curious manuscript collection of accounts, titled Tragic Stories that Took Place in the Kingdom and City of Naples, which traces dozens of these cases throughout the sixteenth and seventeenth centuries, and wherein the authors usually place the blame for adultery on the ever-tempting nature of women. One of the most scandalous of these cases involved the viceroy Pedro Téllez-Girón, Duke of Osuna (1616-1620). Described as having a "great proclivity to lasciviousness", the viceroy abused his position of power by sending local nobles on various missions on his behalf, in a way that freed him to pursue their wives during their absence. Osuna did not always have his way, however, as illustrated by his failed pursuit of one Vittoria Scaglione. Taking advantage of the absence of Scaglione's husband, the viceroy used the help of a servant to furtively enter the house. After overcoming the initial shock of Osuna's intrusion and his indecent expectations, the Neapolitan lady firmly asserted that she would "not damage the honor of her husband in any away". The unyielding Osuna finally gave up, deterred by her strong resistance and her insistence that she "would rather die than having her reputation tarnished". ${ }^{53}$ This should not be too surprising, as the suspicion alone of adultery could seal the fate of contemporary Neapolitan wives. The same sort of honor killings that abounded in Spain occurred also in early modern Naples, where women belonging to the highest ranks of the local aristocracy were executed by their families for adultery, as indicated by the deaths of Ippolita Carafa of Stigliano, Maria of Avalos, Princess of Venosa, and Giulia Orsino, Princess of Bisignano. ${ }^{54}$

Traces of such strong honorific values seem to have lasted among the Neapolitan elite well into the eighteenth century, a time by which most European courtly circles had already embraced the liberating fashions - and the related

52 Jon Cowans (ed.): Early Modern Spain. A Documentary History. Philadelphia, PA 2003, 201.

53 Silvio and Ascanio Corona: Fatti tragici successi nella Citta e Regno di Napoli, Biblioteca Nazionale di Napoli, MS. I. D 36, fols. 239-252.

54 Mastrocinque, Cinquecento napoletano, 552. On noble violence and sexual transgression in Naples see also Gabriel Guarino: Taming Transgression and Violence in the Carnivals of Early Modern Naples, in: The Historical Journal 60 (2017), 1-20. 
looser relations between the sexes - present at Versailles. Indeed, as clearly evidenced by many recent studies, eighteenth-century Italians allowed for the growing role of women in higher spheres of society. This included women's learning and claiming for themselves a significant part in occasions of sociability in the public sphere, as best portrayed in the institutionalization of the salon. ${ }^{55}$ As mentioned above, according to Paolo Mattia Doria, some of the last Spanish viceroys tried to change both the old Spanish costumes and the customs that informed them. Doria traces the change back to the viceroyalty of Gaspar Méndez de Haro, Marquis of Carpio (1683-1687), in which he sees a veritable "process of civilization", to use Norbert Elias' famous term. ${ }^{56}$ During those years, the nobility stopped its dueling and its honorific squabbles and started to embrace the love and knowledge of arts, letters, and worldly affairs. More importantly for us, according to Doria, "most of the nobility started to dress in the French way, and one could witness the birth of a liberty of conversation between ladies and gentlemen.” The abandonment of the modest and grave Spanish garments was thus coupled with the refinement of taste and style, which encouraged new, more egalitarian and interactive forms of sociability. Nevertheless, Doria claims, these changes were done only half-heartedly: men encouraged women to speak freely, but at the same time criticized them in the name of "the good old habits of modesty", causing the women to revert back to their timid behavior. Significantly, according to Doria, those responsible for this situation were none other than the Spaniards, who "implanted in the hearts of Neapolitans the principle of excessive severity towards women, which they compensate with exaggerated signs of admiration and adulation" in an attempt "to shield themselves from a taint on their honor caused by their women's sins." ${ }^{\text {" }}$ A case in point can be seen in the censorious comments made by a contemporary chronicler, deploring the indecency of ladies who appeared in public "exposed down to their breasts and shoulders, a habit invented by the French liberality". 58

Doria's assessment fits well with the observations of the contemporary Vincenzio Martinelli, trying to explain the allegedly Italian eighteenth-century phenomenon of ciceisbeismo, whereby a husband entrusted his wife's good name and reputation to the hands of a gentleman of his confidence, also

55 See the various contributions in: Maria Luisa Betri and Elena Brambilla (eds.): Salotti e ruolo femminile in Italia: tra fine Seicento e primo Novecento. Venice 2004; and Paula Findlen et al. (eds.): Italy's Eighteenth Century. Gender and Culture in the Age of the Grand Tour. Palo Alto, CA 2009.

56 Norbert Elias: The Civilizing Process, transl. by Edmund Jephcott. 2 vols. Oxford 1978-82.

57 For the various quotes in this paragraph see Doria, Massime, 48-50.

58 Fuidoro, Giornali, vol 1, ed. by Franco Schlitzer. Naples 1934, 35. 
known as cavalier servente (gallant servant). This gentleman would be in charge of accompanying the wife in her daily pursuits when the husband was busy, safeguarding the wife's virtue and the husband's honor. Paradoxically, however, many suspicious minds perceived the relationship between wife and gallant servant as an institution of sanctioned infidelity. ${ }^{59}$ According to Martinelli, the custom of keeping a gallant servant was diffused by way of imitation among all fashionable nobilities in the Italian peninsula. The Neapolitans, however, were the most reluctant in adopting it. Indeed, Neapolitan husbands made sure to keep all the rooms of their residence open, and to post guards, ensuring that no one could enter or leave the house unobserved. When leaving the house, every lady would be followed by a second carriage manned by various male attendants who watched her every move. This situation, which Martinelli sarcastically dubbed "a sort of Muslim custody", lasted until well into the 1740s. But twenty years later all of that had changed: "no more second carriages [but rather] conversations, dinners, and magnificent lunches with foreigners, morning visits to the toilettes where the ladies apply their make-up, [replicating] another Genoa, another Bologna."60 Such a belated acceptance of French civilization is probably exaggerated, ${ }^{61}$ but there is little doubt that its full reception was ushered in by the splendid court society of the independent Bourbon court. This was so much the case that by 1739 the French traveler Charles de Brosses would be forced to admit that the sumptuousness of the Neapolitan court surpassed that of Paris. ${ }^{62}$

\section{Conclusion}

In conclusion, our findings show that both men's and women's aristocratic fashions in Naples followed the Spanish tradition during the years of Spain's European political hegemony, which coincided with the strict values of the Catholic Reformation (roughly speaking, from 1550 to 1650). In the case of

59 For a particularly malicious assessment of this practice see Samuel Sharp: Letters from Italy. Customs and manners of that country in the years 1765, and 1766. London 1766, 18-22, 72-75, 210-211, 253-254, 266.

60 Quoted in Elisa Bianco: Le "Notturne Conversazioni”. I cicisbei secondo Vincenzio Martinelli (1770 ca.), in: Mediterranea 8 (2011), 572.

61 The first signs of French forms of sociability are evidenced in the early eighteenth century in: Elisa Novi Chavarria: Sacro, pubblico e privato. Donne nei secoli XV-XVIII. Naples 2009, 132-135.

62 Quoted in Elena Papagna: La corte di re Carlo di Borbone. Il re "proprio e nazionale". Naples 2011, 5. 
women's court dress, it appears that the strict values regarding sexual morality shared by the Spaniards and Neapolitans were paramount in delaying in both countries the success of French forms of socialization and their associated fashions, in comparison with the rest of the major European courts of the time. Things differed in the case of French men's fashions. In the court of Spain, as it had been throughout the Habsburg rule, the process was led by the king's example. However, owing to the strictness of court etiquette and the traditionalist attitudes of Spanish aristocrats, Philip V delayed the full acceptance of French men's fashions until the second decade of the eighteenth century, several decades after the rest of the continent. In Naples, the sartorial choices of men reflected internal scissions within the local elite. Guided by their expensive tastes, and encouraged by the Spanish viceroys themselves, the nobility of the sword started sporting the French habit after the middle of the seventeenth century. The nobles of the robe, by contrast, carried on wearing a black toga and golilla well into the eighteenth century, long after the Kingdom of Naples had become an independent monarchy governed by a Bourbon king, whose court honored the splendid fashions of Versailles. 